\title{
Improved bearing resistance of soil foundations of buildings with injectable polyurethane composites
}

\author{
Sergii Miroshnichenko ${ }^{1}$, Dmytro Plugin ${ }^{1}$, Oleg Kalinin ${ }^{1}$, Alina Zvierieva ${ }^{1}{ }^{*}$, \\ and Ivan Reznichenko ${ }^{2}$ \\ ${ }^{1}$ Ukrainian State University of Railway Transport, Feuerbach sq. 7, 61050 Kharkiv, Ukraine \\ ${ }^{2}$ LLC SPT Ukrayina, Gospitalna str.14, 01601 Kiev, Ukraine
}

\begin{abstract}
The article deals with the analysis of $\mathrm{SPT}^{\circledR}$ polyurethane materials and maintenance technologies based on them, and an analytical review of literature on the topic. Solidification with $\mathrm{SPT}^{\circledR}$ materials and technologies makes it possible to compact unstable foundation soils of structures and buildings. The solidification is implemened through a guided increase of polymeric material injected into a foundation. As a result, polymeric root-like reinforcing bodies are formed in the foundation, and the water is extruded out of the soil, thus considerably increasing the bearing capacity of the foundation. In order to assess the actual efficiency of the material the authors conducted the full-scale research into the general overhaul technology of the pipe culvert, the static and the dynamic tests on the models of solidified soil was conducted and compared with the results of the tests on the models of non-solidified soil. The authors investigated into the life ratio of $\mathrm{SPT}^{\circledR}$ material and the soil solidified with it. By comparing characteristics of $\mathrm{SPT}^{\mathbb{B}}$ materials and technologies with those of conventional materials, the basic analogies and differences were established. And the possibility to use them for construction, refurbishment and maintenance of rail facilities was determined.
\end{abstract}

\section{Introduction}

The use of rail transport facilities on unstable soils, especially watered ones, can lead to irregular soil subsidence, crack development, water resistance failures, initiation of currents, all of which can result in a shorter service life of buildings and possible emergencies [1-3].

In order to improve stability and decrease the water permeability of soils (to create barriers) the following methods are used: mechanical (tamping); drainage (water lowering, electroosmotic solidification due to water electroosmosic and electrophoresis of soil particles when passing direct current); injection; and thermal ones.

Nowadays, the methods based on injection of solidifying materials into soils are becoming more popular. They include cementation (cement solutions), clay grouting (clay

\footnotetext{
* Corresponding author: farwww@ukr.net
} 
suspension), silicatization (sodium liquid glass as a solidifier: two-solution - liquid glass and solidifier by turn, one-solution two-component - mixture of liquid glass and solidifier, one-solution one-component - liquid glass and soil as solidifier, gas - liquid glass and carbon dioxide as solidifier), electro silicatization (combination of electroosmosis and silicatization), soil tarring (polymerizing tars as a fixing agent and a solidifier), and grouting [1-5].

The polyurethane multicomponent materials and maintenance technologies based on them can be regarded as modern injectable compositions of high efficiency.

\section{The analysis of recent research and publications}

Since 1980-1990, European countries have used the high pressure cementation (compensational grouting, soilfrac) to avoid subsidence of buildings with underground works beneath or even to elevate buildings already subsided [5-7]. The pioneers of this technique are Keller Grandbau GmhH (Germany) and Soletanche Bachy (France). At present, the high pressure cementation technology used for underground works (compensational grouting) is being automated. Soletanche Bachy (France) conducted the compensation grouting under the building of Alekseevskiy Military School in Moscow during the construction of Lefortovo tunnel underneath [7].

The solidification technique is chosen according to certain requirements (higher capacity, water resistance), type and soil filtration coefficient, structural peculiarities of foundations, etc. In accordance with a specific construction problem the experts choose the type of the device (injectors, wells), determine the form, outlines and size of solidified soil bodies, establish technical requirements for the solidified soils. The design of solidification requires calculation of limiting states in order to avoid subsidence.

The high pressure cementation is injection of a cement suspension through the system of horizontal full-hole pipes under the subsiding building. The full-hole pipes are placed in advance into the wells drilled from the technological shafts in a fan arrangement under the whole subsiding building or territory. The injection runs under the pressure up to $10 \mathrm{MPa}$ which provides the soil layer fracture and elevation of the daylight ground and building.

Subsiding of the building is controlled with automatic theodolites and benchmarks installed on the building. The data from the theodolites are transmitted to the PC-based control system which analyzes it and generates control signals for the injecting equipment.

The jet grouting technique, developed at the beginning of the 1970s in Japan, has become a common practice in Germany, Italy and France (Jet Grouting, Soilcrete) [5, 6, 8]. It involves mounting soil-cement piles and areas with a cutting jet of the cement suspension.

The jet grouting is applied for any soils subject to washout.

In Europe, leaders in manufacturing jet grouting equipment and those who conduct works are Keller Grandbau Gmb, Bauer (Germany) and Rodio, Soilmec (Italy).

In the 1970s, such technologies and equipment were designed by the All-Soviet Union Institute for Mixed Bases and Foundations (VIOS) and Gidrospetspoekt; they were used during construction of Zagorsk Pumped Storage Station where a barrier of $200 \mathrm{~m}$ in length and $7 \mathrm{~m}$ in depth was built. Nowadays, jet grouting for soils are conducted by such Russian enterprises as Ingeokomspetsstroy (Moscow), Georeconstruktsiya, Geoschit (St.Petersburg), and Region (Perm).

Construction and maintenance of tunnels including underground systems run with the injection of solutions and their treatment $[9,10]$. The objective of this injection is filling hollows and voids left after the construction works with solidifying solutions; it also provides interaction with the surrounding soil. Injection of solutions improves the structural behavior, decreases deformations in processing, prevents subsidence of the soil, increases 
water resistance of the structure and, as a result, lowers the corrosion and extends the service life of constructions.

The injection is conducted in two stages: the initial and the control one. While rating the hydrogeological conditions along the tunnel by the executive documentations (possible elevation of the ground-water level, influences of anthropogenic and other factors), it is a common practice to provide soil packing around the tunnel in order to improve the waterproofness. The division of injections into initial, control and compacting is technologically accepted only for new construction works, and, the operational experience confirms that materials used in wet conditions, as a rule, do not provide needed service life of the barrier.

In order to restore the water resistance behavior and bearing capacity of underground structures, injecting the superplasticized cement-water suspension (SPCWS) in one stage (without dividing into initial and control) is recommended [10]. The SPCWE has the optimal amount of superplasticized additive C-3, Dofen or SL (within $0.2 \div 0.8 \%$ out of the cement mass, defined by a special technique) which provides its high penetrability at extremely low $\mathrm{W} / \mathrm{C}-0.33 \div 0.38$. The injection of SPCWS proceeds to a failure under pressure of $0.5 \div 0.6 \mathrm{MPa}$.

Since the $1980 \mathrm{~s}$, it has been a common practice to inject foam-polymer (usually, polyurethane foam) compositions instead of cement and concrete solutions to provide water resistance for underground structures. The famous Ukrainian polymer composition based on the urethane oligomer Monolit-3 is produced by Monolit-Polymer (Kiev) [11]. It is a three-component composition of resin MA-3, hardener MB-3, and additives polymerization accelerator systems PAS. Compositions added to cement solutions and concretes in the amount $5 \div 15 \%$ out of the cement create waterproof polymer-cement concretes and solutions.

Though the technology was initially developed for transport tunnels, it is successfully applied for renovation of operational properties of underground structures of various purposes.

Searching for a new material as the hardener and stabilizer of underground structures is required, first of all, due to a number of faults in the above-mentioned techniques, namely:

- high cost of the jet grouting technology as the drilling equipment should inject the solution under high pressure with simultaneous rotation;

- silicatization solutions are hardening for 24 hours;

- under silicatization, there is a high possibility for the material to be washed out;

- soils under the structure cannot be solidified;

- silicatization is not an environment-friendly process; and

- high possibility of damages in the structure due to high pressures and large amount of materials;

All the above-mentioned stipulate the need to use a new material of high durability, stability, manufacturability, water resistance for buildings and structures.

\section{The basic part of the research}

Solidification with $\mathrm{SPT}^{\circledR}$ materials and technologies makes it possible to compact unstable foundation soils of structures and buildings. The solidification is implemented through a guided increase of polymeric material injected into a foundation. And as a result, polymeric root-like reinforcing bodies are formed in the foundation, and the water is extruded out of the soil, thus considerably increasing the bearing capacity of the foundation.

Using SPT ${ }^{\circledR}$ materials and technologies for injection prevents penetration of water inside buildings due to improved waterproofing on the building/soil contact, and also the seam sealing between structures and the sealing of cracks in these structures. 
These materials were used for soil solidification under the Main sewage collector in Kiev, under foundations of multistoried buildings, pipes under the railway, soil solidification and slab levelling in Boryspil International Airport and other objects.

The physical and mechanical properties of soils and the bearing capacity of a surface are determined by the soil moisture. If it exceeds the admissible values, deformation processes can be initiated in foundations, often uneven, leading to damages and deterioration to buildings. Therefore, for structures in adverse conditions, such as slopes, under loads from heavy vehicles, with water invasion of the foundations, [11] recommendations are given on constant control of soil moisture; provided it reaches unacceptable values measures for soil draining or solidification should be taken.

In $[12,13]$ the authors show that stability of disperse systems mostly depends on the interaction between the liquid phase and disperse particles. Thus, for higher efficiency of soil solidification it is reasonable to control the hydrophilic and hydrophobic behavior of disperse particles depending on the injectable materials used. The authors believe that solidification with polar substances requires control of the hydrophilic behavior of particles, and with non-polar ones - the hydrophobic behavior.

In order to assess the actual efficiency of the material the authors conducted the fullscale research into the general overhaul technology of the pipe culvert on the $1216^{\text {th }} \mathrm{km}$ of the Kolosivka-Odessa section of the Odessa Railway with injectable polymeric materials. In the framework of the research some models were developed and actual physical and mechanical characteristics of the soils in these models were defined. The static tests on the models of solidified soil were conducted and the results were compared with those on the models of non-solidified soil at various moisture values. The dynamic tests on the models of solidified soil was conducted and compared with the results of the tests on the models of non-solidified soil. The authors investigated into the life ratio of $\mathrm{SPT}^{\circledR}$ material and the soil solidified with it (stability to alternating moistening/drying).

In their research the authors used the soils close by their properties to those of engineering structures on Ukrainian railways (soft loamy sand).

The results of the compressive research demonstrated that the deformation modulus of solidified soil 1.4 times higher than the modulus of soil deformation in nature. However, these results describe only changes in the soil structure after compacting and do not consider the influence of the solidified area of soil-polymeric reinforcing bodies on the bearing capacity.

By the results of static stamp tests on models of the soil area, the authors came to the conclusion that soil solidification considerably decreased its stress-strain behavior (an increase of the deformation modulus). The deformation modulus of non-solidified soil in the model by moisture $W=15 \%$ was $0.5-0.7 \mathrm{MPa}$. The soil solidification increased the modulus at $W=10.9 \%$ up to $11.2 \mathrm{MPa}$ and at $W=6.9 \%$ up to $33.4 \mathrm{MPa}$. Though the deformation modulus increased due to soil dewatering at $W=11.5 \%$ up to $3.9 \mathrm{MPa}$, at $W=9.5 \%$ up to $33.5 \mathrm{MPa}$.

The analysis of the research results by deformation characteristics demonstrated that during the static tests on the solidified soil the dependencies of the modulus of elasticity $E$ on moisture $W$ were demonstrated by the diagrams in Fig. 1. These dependencies are approximated by exponential equations with the correlation coefficient 0.99 for nonsolidified soil and 0.77 for solidified soil. According to these equations, presented in Fig. 1, the dependency of deformation modulus $E$ on soil moisture $W$ for natural and solidified state was calculated.

The analysis of the calculation results allowed the authors to propose the coefficient of a higher deformation modulus after solidification $K_{E}$, the dependency of the deformation modulus of solidified soil on the deformation modulus of the natural soil at equal moisture, in order to evaluate the influence of solidification on the stress-stain behavior of the soil. 
The values of these coefficients are given in Fig. 2.

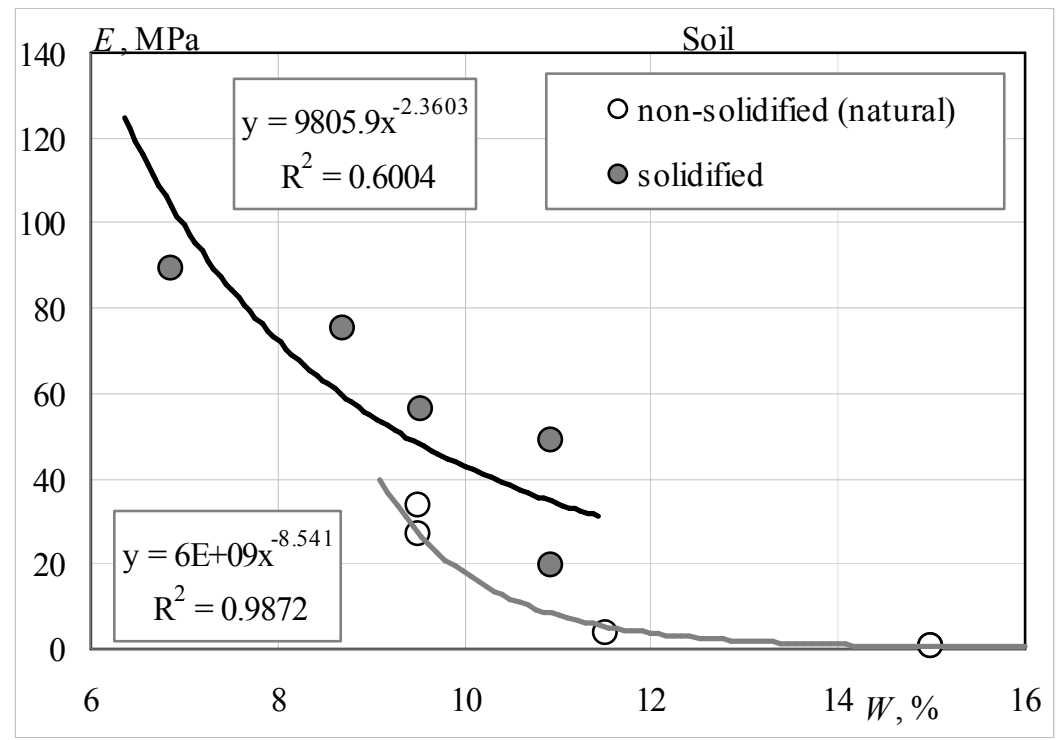

Fig. 1. Dependency of deformation modulus $E$ of natural and solidified soil on moisture $W$.

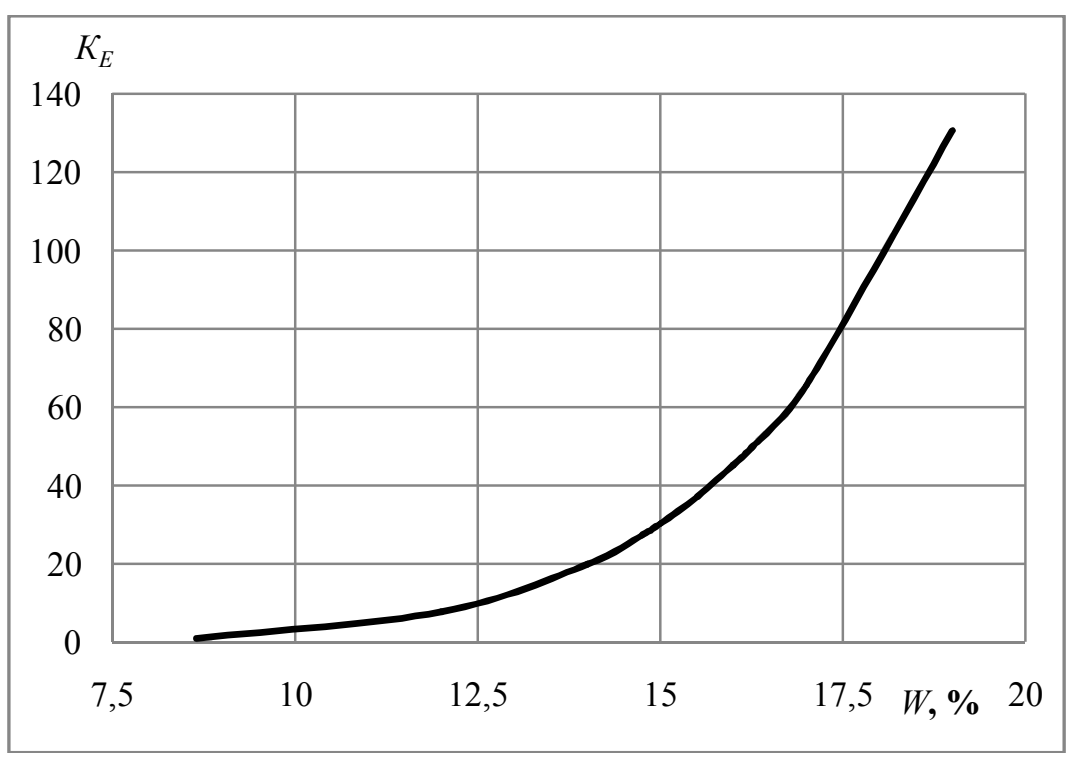

Fig. 2. Dependency of the coefficient of a higher deformation modulus after solidification $K_{E}$ on soil moisture in nature.

Fig. 2 demonstrates that in dry soils (loamy sand) with moisture less than $8.6 \%$, solidification does not increase the deformation modulus (does not decrease the stress-strain behavior). For wetter soils, the deformation modulus is increasing due to solidification, at the moisture:

- $10 \%$ - by 2.5 times (from 17.3 to $42.8 \mathrm{MPa}$ );

- $14 \%$ (elasticity limit) - by 20 times (from 0.98 to $19.4 \mathrm{MPa}$ );

- $15 \%$ (middle of the plastic stage limits - by 30 times (from 0.54 to $16.4 \mathrm{MPa}$ );

$-16 \%$ (liquid limit) - from 0 to $12.2 \mathrm{MPa}$. 
The authors believe that these dependencies will cover all loamy and sand-loamy soils. However, it can only be confirmed by the research into soils with other factors of elasticity and liquid limits.

Durability of joint work of the soil/polymer system under the conditions without weathering and insulation will depend on influence of water, especially, on changes in water saturation. The actual foundations of rail transport structures yearly suffer from twocycle changes in water saturation level. Therefore, in order to evaluate durability of the soil/polymer system the unique research procedure was designed.

Thus, the authors modeled the effect which was definitely destructive for the polymersoil body (the root-like body taken out of the model and formed by the polymer with soil particles or particles glued with the polymer). This effect was very intensive alternate moistening/drying which eventually ruins virtually all construction composite materials.

By the results of the research into the influence of the alternating moistening/drying of the solidified soil samples on their properties, it was established that the influence ruined the soil, notably led to mass loss both in a dry and water saturated states. After each moistening/drying cycle the difference between the mass in dry and wet states increased, which testified to higher porosity, and, therefore, changes in the stress-strain behavior and soil stability.

Additionally, for the reason of comparison, the similar tests on the soil solidified with one-agent silicatization with silicon hydrofluoric acid as a hardener were made. It is a wellknown fact that the durability of such solidification under the conditions of underground waters is $10-15$ years.

The research into the influence of the alternating moistening/drying on the samples of solidified soil showed that if solidification was done with $\mathrm{SPT}^{\circledR}$ materials and by SPT ${ }^{\circledR}$ technology, the samples lost $5 \%$ of their mass in 10 cycles, while silicatization gives a loss of $10 \%$ of the mass in 2 cycles. Considering the soil solidification durability by silicatization as 15 years, the life expectancy of solidified soil with SPT $^{\circledR}$ material is no less than 75 years.

The petrographic research demonstrated that unlike traditional chemical soil solidification with silicatization or tarring, which provide even infiltration, SPT ${ }^{\circledR}$ materials and technology provide formation of root-like reinforcing elements in the soil. Some of these roots had the lateral dimension up to $70 \mathrm{~mm}$ and consisted of the middle and peripheral zones. The middle zone was a layer of porous well-polymerized material, and the peripheral zone was soil-polymer composite consisting of porous polymerized material and soil particles.

\section{Conclusions}

In order to assess the way of improvement of the bearing capacity of soil by solidification with SPT ${ }^{\circledR}$ materials and by SPT ${ }^{\circledR}$ technology, the authors propose to use the coefficient of a higher deformation modulus after solidification $K_{E}$ (the ratio of deformation modulus of the solidified soil to the deformation modulus of natural soil at the same moisture) for calculations.

The research into the influence of alternating moistening/drying on the samples of solidified soil demonstrated that solidification with $\mathrm{SPT}^{\mathbb{B}}$ materials and by $\mathrm{SPT}^{\mathbb{B}}$ technology predicts the life expectancy of more than 75 years.

Therefore, the sphere of application for SPT ${ }^{\circledR}$ materials and technology is wider than that of traditional chemical soil solidification with silicatization or tarring (used only for sands and porous foam soils) and can be extended to practically all clay soils. Though, this conclusion can only be confirmed on conducting a full complex of tests on other soils. 


\section{References}

1. A. Plugin, L. Trykoz, Vidnovlennya ekspluatatsiynih vlastivostey osnov, fundamentiv, zagliblenih i pidzemnih sporud (Kharkiv, UkrSURT, 2005)

2. A.M. Plugin, A.A. Plugin, L.V. Trykoz, O.S.Sayapin, O.S. Herasimenko, O.A. Plugin, Rozrahunki nesuchoyi zdatnosti $i$ tehnologiya zakriplennya osnov budivel $i$ sporud zaliznichnogo transportu (Kharkiv, UkrSURT, 2012)

3. M.I. Smorodinov, B.S. Fedorov, B.A. Rzhanitsyin i dr., Osnovaniya i fundamentyi: Spravochnik stroitelya (Moskva, Stroyizdat, 1983)

4. B.A. Rzhanitsyin, Himicheskoe zakreplenie gruntov v stroitelstve (Moskva, Stroyizdat, 1986)

5. Tehnologii rekonstruktsii fundamentov. Rekonstruktsiya gorodov i geotehnicheskoe stroitelstvo, www.georec.spb.ru (2003)

6. V.V. Savyovskiy, O.N. Bolotskih, Remont i rekonstruktsiya grazhdanskih zdaniy (Kharkiv, Vaterpas, 1999)

7. Zh.-L. Valett, Metro i tonneli, 4, 16-19 (2002)

8. A.G. Malinin, Metro i tonneli, 4, 14-15 (2002)

9. Rekomendatsiyi z gidroizolyatsiyi tuneliv metropolitenu za dopomogoyu tsementnih kompozitsiy (Kharkiv, Mintrans Ukrayini, Ukrzaliznitsya, 2001)

10. TsP-0136 Instruktsiya schodo vikonannya robit z nagnitannya rozchiniv za obrobku tuneliv (M-vo transportu ta zv'yazku Ukrayini, Derzhadministratsiya zaliznichnogo transportu Ukrayini, Ukrzaliznitsya, Golovne upravlinnya koliynogo gospodarstva, 2006)

11. A. Plugin, L. Trykoz, O. Herasymenko, Ant. Pluhin, V. Konev, Diagnostyka. 19 (2), 13-23 (2018)

12. A. Plugin, E. Dedeneva, T. Kostyuk, D. Bondarenko, O. Demina, MATEC Web of Conference, 116, 01010 (2017)

13. A. Plugin, T. Kostiuk, O. Plugin, D. Bondarenko, Yu. Sukhanova, N. Partala, International Journal of Engineering Research in Africa, 31, 59-68 (2017) 